\title{
First World War - Recent Publications
}

1. Margaret MacMillan. The War that Ended Peace: The Road to 1914. Toronto: Allen Lane, 2013. xxxv + 739 pp., illus., maps, ports. \$35.00; ISBN 060064041.

2. Christopher Clark. The Sleepwalkers: How Europe Went to War in 1914. New York: HarperCollins Publishers, 2012. xxxi+697 pp., illus., maps. US\$29.99; ISBN 9780061146657.

3. Max Hastings. Catastrophe: Europe Goes to War 1914. London: William Collins, 2013. xxxvii+ 628 pp., illus., maps, ports. £ 30; ISBN 9780007398577.

4. Michael S. Neiberg. Dance of the Furies: Europe and the Outbreak of World War I. Boston: Harvard University Press, 2011. 336 pp., illus., maps. US\$18.95; ISBN 9780674725935.

5. Phillip Blom. The Vertigo Years: Change and Culture in the West, 1900-1914. Toronto: McClelland and Stewart, 2008. 480 pp., illus. (some colour); ISBN 0771016301.

6. Gerard DeGroot. Back in Blighty: The British at Home and World War I. London: Vintage, 2014. 496 pp. £9.99; ISBN 9780099582229.

7. Mark Bostridge. The Fateful Year: England 1914. London: Viking (The Penguin Group), 2014. xxviii+ 404 pp., illus. £19.99; ISBN 0670919217.

8. Gwynne Dyer. Canada in the Great Power Game 1914-2014. Toronto: Random House Canada, 2014. 423 pp., illus., ports., facsimiles. \$34.95; ISBN 9780307361684.

The globe that was Europe, for it was Europe's globe, was shattered by the events of the Great War that broke out in August 1914 and nominally ended with the armistice of November 1918, with ongoing regional conflicts and civil wars into 1919 and beyond. We began to commemorate in 2014 its sobering and melancholy centenary. We will continue to do so for the next three years. The war was easily the most significant world event since the conclusion of the French Revolutionary and Napoleonic Wars a century earlier. It marked a clear dividing line between the era of world dominance by the European empires and their replacement by rising new powers. The consequences of the Great War are with us still, reverberations that we see daily in the news of regions where conflicts were supposedly "settled" by that conflagration and the peacemaking that followed. The Great War was the precursor of the Second World War, an even more violent and horrific bloodletting, that has directly built the world in which we live. However, without the first global conflict there would not have been a second.

It is certainly safe to say that no belligerent of the Great War would have entered it had its ultimate cost in lives and treasure been apprehended. The leaders of the empires that vanished - Germany, Austria-Hungary, Russia, and the Ottoman Empire - would clearly have found a different solution to their troubles rather than marching on their neighbours and towards doom. The "winners" were no better off with the human cost at 
incomprehensible levels, making the totting up of the victorious balance sheet an obscene exercise. They too would have perhaps found some compromise to avoid the conflict had they understood the price of their firm resolve to see off the aggressor. However, once underway all participants found the war's unyielding logic, the need to see it through, to justify the sacrifice made thus far, to defeat the enemy, to win a new world, conspired to make compromise impossible. Thus the war's own momentum carried it through to the conclusion, in ruin and wreck.

It is important to understand that views on the war, particularly its costs in lives, were different at the time than from today's perspective. Our comprehension of the conflict has been coloured by the literary outpourings of a highly educated and articulate elite during the war, and novels and memoirs that appeared in the late 1920s. None of these reflect the views of the ordinary soldier or officer. There was a grim determination to see things through, to endure, and to do one's duty. And, perhaps amazingly so, there was humour and pathos as the war ground on. Life was much harder for ordinary people one hundred years ago, work conditions were often very poor, industrial accidents common, and life spans much shorter than what we presently enjoy. The ability of combatants to endure seems remarkable today, but perhaps was not so surprising at the time. The amateurish conduct of the war is also difficult to fully grasp. Soldiers went into battle with the most rudimentary military capacities and training. Communications at all levels was primitive, and the ability of generals and colonels to actually manage the battle in a modern sense almost entirely absent. All learned as the war ground on. Indeed, there was growing skill and competence from this very rocky beginning (for at least the British Empire forces) that was paid for in the daily casualty lists we can barely grasp today. At the end there was satisfaction and pride with the job successfully done.

In Canada, the First World War is not well understood by most Canadians, save for a vague sense that the Battle of Vimy Ridge represents our nation's coming of age, and that some fellow named McCrae wrote "In Flanders Fields." More than that is a rare degree of knowledge - mind you, a solid grasp of any aspect of history (or geography, or civics, I could go on) is not a discernible attribute of the modern high school graduate as most educators and concerned parents might concede. In August 1914 Canada went to war automatically and without debate on Great Britain's declaration of war on Germany. The news was conveyed from London by telegram to Ottawa. In Versailles after the war, Canada signed the peace treaty, and the prime minister, Robert Borden, played an active role in the negotiations in concert with his peers from the sister dominions, Australia, New Zealand, and South Africa. The war completely changed the dominions' relationship with the Mother Country and it has indeed been correctly defined as Canada's coming of age in important ways. But Canada, so very "British" in 1914, was no less so in 1919, and the sentiment of the country, excepting Quebec's understandably ambivalent attitude to matters European post-1763, was very much with the Empire of which it was a proud part. A hundred years later this has largely gone, albeit there remains some lingering nostalgia in the hearts of some citizens. This heritage is an important part of our national identity and inheritance from Great Britain, and reminding ourselves of our roots is a useful enterprise. 
For all these reasons, it is worthwhile to examine a range of books that have recently been written about the First World War and to reflect on what happened, and perhaps consider what that war means for us today. The books I have selected for this purpose are by no means comprehensive, but I think them worthy of examination as much important and new work on the war has been done in recent years with the promise of more to come. I have focused mainly on books explaining the outbreak of the war, commencing with Margaret MacMillan's examination of the topic, as well as looking at a number of books that explore the cultural back drop of the societies that became engaged in the war. I have included one volume dealing with the war's conduct because of its broad coverage of the conflict, but have generally kept away from "military and naval history." I conclude by looking at Gwynne Dyer's book on Canada and great power conflicts as an appropriate note on which to finish.

Margaret MacMillan almost certainly needs no introduction. She is an Oxford academic with Canadian roots, and is the author of, inter alia, the notable bestseller Paris 1919: Six Months that Changed the World. This latter book explored the process and outcome of negotiations that led to the Treaty of Versailles that formally concluded the Great War. Her current book, The War that Ended Peace: The Road to 1914, provides the opposite bookend to her previous, and is almost certain to repeat the success of the first.

MacMillan starts her book with an examination of one of the first examples of German "frightfulness," the sack of Louvain in late August 1914. This atrocity was initially occasioned by a minor setback inflicted on the German Army by the Belgians, which led to panicked German soldiers shooting at shadows, in turn leading to escalation and reprisals. The end result was looting, burning and, it cannot be otherwise described, sheer pointless vandalism, which included the burning of the famed library at the eponymous university (established 1425). And so total war got well underway.

The book opens with an important question: why did Europe go to war in 1914? There had been a century of continental peace since 1815 . There had been, it is true, a number of conflicts in the preceding century, but these had been on the edges of the Europe proper (e.g. the Crimean War), or had been short and decisive (e.g. the FrancoPrussian War). There was nothing like the conflagration that engulfed the continent from 1792 to 1815 . In the years prior to the outbreak of hostilities in 1914, there had been a series of crises, almost all of them minor, and all resolved without great power conflict. The Balkan squabbles in 1912-13 were unseemly and in a region that was a byword for instability, but not important in the greater scheme of things. Surely not? Why was the assassination of the heir to the Austrian-Hungarian throne the flash point that led to a general war in 1914? What was unique about this event that proved unresolvable without recourse to war? What was so different to the previous upheavals that had been sorted out without such a horrific outcome?

In the end MacMillan concludes that complacency and a failure of imagination led to the war's outbreak, and that the preceding fifteen years of experience had taught the leaders of the protagonist powers that some last second resolution would be found. And, if not, then best to get what many considered an inevitable conflict over and done with. The failure of imagination lay not in the search for resolution of the immediate 
crisis of July 1914, but in grasping what war meant, what it would likely cost in lives and treasure, and, potentially in the last extremity, in terms of national survival. Evidence was readily discernible to the curious. Had the likely consequences been widely grasped and reflected upon, she suggests, a solution would have been found and the war avoided. There are always choices and nothing is inevitable.

This is surely right.

An important theme that MacMillan develops throughout the book is the role of individuals in determining the fate of nations. The character, motivations and behaviour of monarchs, presidents, prime ministers, generals, and politicians are all important and relevant in explaining the outbreak of war. This view is perhaps at odds with the "forces of history" school of thought and is instead aligned with the "great men" perspective as the essential explanatory factor of events. MacMillan therefore places responsibility for decisions on the shoulders of the men who made them, rather than suggesting that they were puppets controlled by external factors beyond anyone's influence. This is surely right.

MacMillan's book is well written and a good read. It does have a number of minor errors of fact (e.g. the first day of the Somme being 2 July 1916 - p. 636), but these are no more than a minor distraction. Her character sketches are illuminating and her exposition of the complexities of the years leading up to 1914 well done. In short, this is a fine companion volume to her earlier Paris 1919.

In The Sleepwalkers: How Europe Went to War in 1914, Christopher Clark has adopted a view similar to MacMillan's: individual politicians and military leaders led the way to war through their decisions, their miscalculations, and their misconceptions about what was at stake. Unlike MacMillan, who lays more of the responsibility for the outbreak of war on Germany, its militarism, and its unstable monarch, Kaiser Wilhelm II, Clark concludes that the outbreak was a blundering tragedy, occasioned by miscalculation and bad luck on the part of all belligerents. Clark also focuses attention on the Balkans, which in his view is the locus of events leading to the war. Had that fissiparous region been stable and well governed it is unlikely in the extreme to have driven the great powers to war. A big if indeed.

Clark begins with an extended exploration into the murky realm of Balkan politics, starting with the gruesome 1903 murder of the king and queen of Serbia by army officers unhappy with the ruling dynasty. The leader of the conspiracy, Dragutin Dimitrijević, who later headed the Serbian secret service, was nick-named "Apis," after the Egyptian bull-man god, lending a touch of near fictional flair to the episode. Apis later fatefully armed and sent on their way the conspirators and assassins who killed the Austrian Archduke Ferdinand and his wife in Sarajevo in June 1914.

The fundamental difficulty with the Balkans in geo-political terms was the competition for influence and territory by the emerging nations springing forth from the decaying Ottoman Empire. Longstanding rivalries and interests in the region justifiably involved Austria-Hungary as a direct neighbour, and Russia, perhaps less so, as a protector of its "southern Slav" racial and cultural confrères. Russia was also deeply 
anxious about access to the world's trade routes through the Bosporus and Dardanelles for its grain and other products. Wars had been fought on this question, notably the Crimean War of 1853-56 and the Russo-Turkish War of 1877-78. The Balkans were a seething mass of conflict and struggle for dominance and land as the relatively benign and light hand of the Ottomans atrophied, withered and disappeared as the nineteenth century drew to a close. A central irritant was Austria-Hungary's advance into BosniaHerzegovina, which became a protectorate in 1878, and then, in 1908, a province of the empire, developments that Serbia and other states in the region viewed as entirely illegitimate.

With the table thus set, Clark explores the chanceries of Europe through the Balkan prism. There is much to commend this approach. From it most of the steps that were subsequently taken by St Petersburg, Vienna, Berlin, Paris and, fitfully, reluctantly, London can be discerned. Clark is brilliant in his review of the complexities confronting the various personages that ran the world in the decades leading to the Great War. Like MacMillan he notes the personalities, weaknesses and strengths, prejudices and assumptions of the players and their role in the events as they unfolded. His conclusion is that tragedy, not culpability, is the explanation for the war's eruption, and like MacMillan, that it need not have happened.

Important as the Balkan's certainly were in triggering the war, the levers were pulled by hands in far more important centres than Belgrade or Constantinople. Much has been written about the rival alliances that were established in the twenty-five years prior to the Great War. A common view is that the rigidity of the alliance structure virtually ensured that some minor squabble would at some point ineluctably lead to a general conflagration; the whole of Europe was a tinderbox awaiting the fatal spark. Clark does not accept this view and he musters much evidence to the contrary. The alliances were not iron-clad, as in Britain's anything but certain commitment to France and Russia. Critically, Germany's specially issued "blank cheque," rashly provided to an outraged Austria-Hungary as it sought to make Serbia pay for its support of the assassins, demonstrated that obligations among the Central Powers were far from automatic. Moreover, that alliance's third partner, Italy, bowed out and eventually joined the Entente. Certainly alliance commitments did not dictate that the dominoes fell as they did,. The contingent nature of the war's outbreak is, perhaps, an important lesson for present day leaders as they contemplate their response and responsibilities in myriad challenges to peace.

Clark's metaphor of "sleepwalkers" is apt. More contentious are his conclusions regarding culpability, and this is not surprising. Responsibility for the Great War has remained a divisive and controversial question since 1914, and was most emphatically not answered by the judgement of German guilt made by the victorious powers in the Treaty of Versailles in 1919. Clark essentially concludes that guilt required a will to a general European war for which there is no evidence. Missteps abounded on all sides and hence, he argues, no one power was truly guilty. Yet the evidence amassed by Clark, and his assessment of that evidence, show that German behaviour and decisions were the critical factors notwithstanding his nuanced conclusion that assigning blame is without profit. 
Both Clark and MacMillan's tomes end with the outbreak of the war. Max Hastings, a well-known military historian and journalist, has written a conventional account of the war's first five months - August to December 1914. The main body of Catastrophe: Europe Goes to War 1914 masterfully retraces the opening campaigns on both the Eastern and Western Fronts. Hastings, in his brief but insightful look at the war's outbreak, notes that the controversy over responsibility for the conflict will never be conclusively resolved as the plethora of evidence permits a wide range of plausible interpretations. As the above discussion on the Clark and MacMillan volumes suggests this is a not unreasonable conclusion.

Hastings opens with Churchill's observation that "No part of the Great War compares in interest with its opening. The measured, silent drawing together of gigantic forces, the uncertainty of their movements and positions, the number of unknown and unknowable facts made the first collision a drama never to be surpassed. Nor was there any other period in the War when the general battle was waged on so great a scale, when the slaughter was so swift or the stakes so high. Moreover, in the beginning our faculties of wonder, horror and excitement had not been cauterised and deadened by the furnace fires of years." As is so often true, Churchill is a shrewd observer and I think most will agree that the outcome of the first months set the stage for the balance of the war. If the decisive result that was confidently expected by many was to unfold as scripted, then this was the period in which these expectations were dashed.

The first campaign covered is that of the Austro-Hungarian forces against Serbia. It is an appropriate beginning given the role of Serbia in triggering the conflagration that engulfed the continent. The performance of the Austro-Hungarian army was unimpressive to understate matters. Serbia defended itself with vigor and, despite suffering significant losses, managed to retain most of its territory after a see-saw series of engagements fought in primitive conditions by poorly led and equipped armies on both sides. By the end of the year Serbia was holding its own, but the writing was on the wall and, at the same time, the seeds of Austria-Hungary's eventual collapse were well and truly planted.

However, the heart of the book is the titanic clash on the Western Front - in Alsace and Lorraine, Belgium, on the Marne, the Aisne, in Artois and Flanders. To a contemporary reader the sheer ineptitude of the conduct of war can only be considered criminal. The losses suffered by the French as they sought to avenge the humiliation of 1870 are simply beyond comprehension. On one day, 22 August, with the war barely three weeks old, the French Army lost 27,000 men killed in the Alsace-Lorraine region, a far higher total than the British suffered on the First Day of the Somme, some two years later. The Germans also suffered severely, losing many more men than anticipated in defending against the French attacks as well as dealing with the unexpectedly robust and ferocious Belgian defence of their homeland. By the end of the year, the French had suffered casualties of over one million, including some 330,000 dead (or some 2200 deaths per day). The Germans lost approximately 800,000 killed, wounded and missing. The British casualties approached 90,000 out of an initial force of 120,000. These were

1 Hastings, quoted in Introduction, p. xvii. 
losses of a scale that are scarcely comprehensible today and all suffered in only 150 days.

Hastings is an accomplished author who writes knowledgeably and with verve. This book is the first of his oeuvre on the Great War, but he knows the material well. He includes solid descriptions of the higher level conduct of the campaigns of 1914, and peppers the account with vignettes from the participants. This is an engaging and compelling narrative.

Michael Neiberg's book Dance of the Furies, shifts the focus from those charged with the destiny of nations and follows the stories of befuddled citizens across Europe as the continent descended into the maelstrom of war. Neiberg provides a useful corrective to the common view that Europeans of all nations were straining at the bit and anxious to get at their "traditional" enemies, that the continent was the proverbial powder keg awaiting the inevitable spark. Indeed, the more common view was that the whole July crisis would blow over, as had the previous crises, and that it was unthinkable to go to war. The diplomats would sort it out - no worries. Neiberg has accumulated a vast range of observations and perspectives from the ordinary soldiers, ordinary citizens, caught up in the initial 1914 campaigns. He has clearly demonstrated that war was greeted with bewilderment and an anxious and earnest desire for a speedy end.

Neiberg, an American academic from the University of Southern Mississippi, has built his account around six major themes. The first is that no one expected a war in 1914 and that no one really wanted one. Even the French, presumably keen to reverse the humiliation of 1870 were not, in point of fact, willing to go to war to recover the lost provinces of Alsace and Lorraine. Neiberg's second contention, built upon his first, is that modern thinkers have overemphasised the role of nationalism in how the war was understood and supported by the combatant populations. Indeed, the citizens of all countries rallied around the flag (albeit with significant ranges of enthusiasm) in the hour of need. But there were many identities other than nationality, including class, gender, ethnicity, religion, occupation, and political persuasion. Most supported their country and most soldiers willingly served (either as volunteers or as conscripts), but that support was not an unthinking adoption of the propaganda driven agendas of their various governments. There were many links that reached across borders - e.g. socialism - and hence commonalities, particularly in thought, among the peoples on both sides of the conflict.

A further theme developed by Neiberg was that most citizens, be they soldiers or otherwise, considered that their particular country was fighting a defensive war against aggressive enemies. Certainly the British and French had no trouble with this perspective, and indeed most modern observers would basically agree - after all, the German Army had attacked across the border with France and attacked, unprovoked, Belgium. But, the Germans by and large felt themselves on the defensive because of the attacks from Russia in the east. The war with Russia's ally France was therefore defensive. Similar arguments prevailed wherever you look as the war unfolded. This basic conception meant that virtually all combatants saw themselves defending kith and kin and hearth and home.

Importantly, and as a fourth theme, Neiberg noted that horror, disillusion, shock, 
and a hardening towards visible suffering were well established by December 1914. The bloodbaths of 1916 and 1917 were yet to come, but within five months these perceptions were common. It is often not well understood that the war's bloodiest months were in 1914. The shock of the initial casualty lists never wore off - understandably - albeit that shock was endured to an extent that it is difficult to understand a century later. Neiberg has found a wide range of reactions to the war from all sides that spoke to the disillusion that had set in quickly in these early days. His final two themes were that once the war was under way, all belligerent nations supported it with determination. And, this support was maintained throughout the war till the very last weeks. Most believed that the suffering had to be endured, the losses borne, because only in victory could they be justified and the very much feared consequences of defeat avoided. A ghastly Hobson's choice.

The book is very well done and provides an important window into the perceptions of those lower down the ranks from the war's earliest days. Neiberg has also shown the commonalities in these perceptions no matter the nationality involved. $\mathrm{He}$ does concede that evidence from Eastern Europe is less comprehensive and available, but he has tapped into some sources that are at least indicative and supportive of his thesis. Neiberg's effort to get into the mentalite of the era is entirely commendable and is always very difficult to accomplish. It is perhaps even more challenging when that era is comparatively close by and the assumption is made that one's grandfather is just like one's self. He isn't and wasn't.

A second title that also strives to understand the mentalite of the age is Philip Blom's The Vertigo Years: Change and Culture in the West. 1900-1914. This book was published in 2008, and so is not as recent as the other volumes treated in this essay, but it provides invaluable insight into cultural developments that helps set the scene for the Great War. Blom organised his book by year, featuring a theme that was predominant, or first came to more general attention, during that year, usually with a focus on a particular country. 1900 was the Paris World Exhibition, which scarcely masked the French sense of decline - of birthrates and of military power - amidst decadence, anti-Semitism (the Dreyfus affair), insecurity and anxiety. 1901 was the coronation of Britain's Edward VII, and marked the end of an era of glory and certainty as reflected in Victoria's Golden Jubilee of 1897. This was the year of Kipling's poem Recessional, of Arnold's Dover Beach and a wider awareness of the economic eclipse of the aristocracy, a casualty of free trade in agricultural products and an evolving globalisation of trade that was mirrored by the decline of the aristocratic class throughout Europe. Often, of course, the themes highlighted in each year had an ongoing influence, which the narrative traces.

What Blom investigates is the myth of the Edwardian Age - that period from the turn of the century to the outbreak of war that encompassed the brief reign of Edward VII of Great Britain. This short era is often portrayed as an idyllic period, where all was peace and tranquillity, dappled lawns predominated, Oxford's dreaming spires dreamed, labourers laboured, aristocrats promenaded. Businessmen, colonial administrators and government bureaucrats industriously provided the fruits of a prosperous and dynamic economy to all, and everyone knew their place: in short, a marvellous interlude between 
the myriad struggles of the often Dickensian Nineteenth Century and the horrors of the Great War. That this is myth is quite apparent after the most cursory examination of those years, but it is an enduring one and Blom tackles the question wonderfully. $\mathrm{He}$ points out this period has a resonance with the present in political controversy, cultural ferment and social upheaval, the demands of educated women for their rightful place and men's resistance, technological innovation, dramatic developments in science and art, the rise of mass consumption, revolutions in communications media, and, above all, speed of change - hence, vertigo. It was a deeply uncomfortable time. The Great War did not create these forces. It was partly their product and also their catalyst, with the strains and dislocation of the pre-war years continuing into the 1920s and 1930s when modernity as we understand it took hold.

Blom's theme is that these forces have re-emerged in the twenty-odd years since the collapse of the Soviet Union and that the uncertainties of the early twentieth century are matched by similar uncertainties today. This is an interesting argument, but not entirely to my purpose in selecting this book as I find Blom's portrait of the pre-war period, in and of itself, compelling and illuminating. It is all too easy to get swept up by the military or naval aspects of the war and its origins. A very natural focus, of course, but insufficient to really grasp from whence the conflict sprang. Blom is an excellent guide and I know of no better exposition of the cultural milieu and zeitgeist of the very troubled years before the war's outbreak.

The next two books in this idiosyncratic collection address the scene in Great Britain more specifically. The first is Mark Bostridge's The Fateful Year: England 1914. Bostridge opens with reference to Larkin's "MCMXIV," a poem evoking the innocence and imagined halcyon days of the pre-war Edwardian era, and the horrors unexpectedly unleashed on 4 August. However, this supposedly prosperous and innocent time was anything but. The year saw profound domestic discord in England, and Great Britain more generally, so much so that the spot of bother in the Balkans was generally ignored or dismissed as irrelevant. (Not, it needs to be noted, that this was an overly insular view - the two previous years, 1912 and 1913, had seen two Balkan wars whose impact had been safely limited to that region. Why wouldn't the current mess be similarly confined?)

There were three major issues that were placing enormous stress on establishment Britain, including the suffragette movement, the Home Rule for Ireland imbroglio, and industrial unrest as the working class sought a fairer shake from their employers. Naval and European military matters were not on the immediate horizon. The Irish question was perhaps the most unsettling as it threatened civil war. The suffragettes were active, vociferously so, right in the heart of country and were impossible to ignore. Indeed, there was not much space available for foreign affairs in the Britain of 1914.

Bostridge split his account into three portions - the first on events from January through April, the second on the May to August period, and the final on the five war months from August through December. The book explores the key issues that arose with idiosyncratic digressions into minutia designed to give a sense of society at the time. 
The account of an unsolved murder of a five year old boy that transfixed London in early 1914 dominates an early chapter. Its inclusion in the narrative perhaps serves as a reminder that such sordid tragedies transfixed society as much then as now. This is followed by an excellent, and rather more significant, examination of Brigadier Gough's conduct and that of the Army Council regarding the events of the Curragh Mutiny. The latter incident arose out of the growing danger of civil war in Ireland over the implementation of Home Rule from Dublin in the Catholic south, and the Army's unhappiness with its likely role quashing resistance from the Protestant northern counties. This topic is enlivened with a description of Prime Minister H.H. Asquith's infatuation with Venetia Stanley, a young woman of an age to be his grandchild. It was a relationship that acted as a safety value for the embattled prime minister, whose domestic life was sterile and loveless, yet nonetheless odd for all that. An examination of a pupils' "strike" in Herefordshire is juxtaposed with a digression into industrial unrest more generally. In this context the "Triple Alliance" of the railwaymen, transport workers and miners seemed much more relevant to most Britons than the Triple Alliance that dominates diplomatic narratives. A recounting of the slashing of the celebrated seventeenth century painting "The Rokeby Venus" by a suffragette in protest at the inhumane treatment of Emily Pankhurst in prison is accompanied by an examination of art, its place in society, and how many were more upset at the vandalism than by the conditions imposed on suffragettes in His Majesty's prisons.

All in all this is a highly variegated sketch of the English scene in its bewildering complexity. The sense is of an inward looking, self-absorbed society that was engaged in its own troubles to the exclusion of much else, let alone news from the far away and deeply obscure Balkans. This reality explains the deep shock of war when it came. It was not a "bolt out of the blue" if you were looking, but most were not looking.

The final third of the book covers the 1914 war months. The second chapter in this section touches on the raising of Kitchener's first 100,000 volunteers for the army for a war that he accurately predicted would continue for at least three years, not a couple of months. Bostridge recounts that the flood of volunteers and wild enthusiasm for the war was not fact. There were isolated expressions to be sure, and the support to the King at Buckingham Palace was vocal and heartfelt. But there was little more. A two week period in late August indeed saw huge numbers of volunteers, but it was two weeks only, and two weeks that were never repeated. An interesting digression examines the role of the "White Feather Brigade" of nasty-minded women and retired Colonel Blimps who handed out white feathers of cowardice to seemingly fit young men not in uniform in an unflattering reflection on English society. A number so accosted committed suicide, so it was not all a joke after all. Observers at the time concluded that the ideal of an allvolunteer army in contrast to the conscripts that populated the armies of the other belligerents was rubbish. An army that involved the coercion via public disapprobation was not so much composed of willing "volunteers" at all. This is all counter to the received view.

Another chapter explores the extraordinary endeavours of a bereaved mother, Violet Cecile, whose son died with the Irish Guards in a murderous and confused scuffle 
near the village of Villers-Cotterêts on 1 September - barely a month into the war. The Germans secured the area and hastily buried approximately 160 men from the Brigade of Guards, including George Cecil, Violet's son. What the recounting of Violet's search reveals is sheer confusion and lack of news regarding the soldiers that accompanied the dreaded "missing in action" bulletin from the War Office (usually after a significant delay). The agony of anxiety is not to be wondered. However, Violet, married into the Marquis of Salisbury's family, was not a typical mother; she had connections, she had pull. Efforts were made on her behalf in London, Paris, Amsterdam and, astonishingly, Berlin, to see if George had somehow survived and was a POW. It all came to naught. Ultimately, the village of Villers-Cotterêts was retaken and the hasty grave was opened in mid-November and efforts made to identify those killed. George's body was identified by his brother who recognised his watch. Most mothers in a similar position to that of Violet, of course, learned nothing about the ultimate fate of their missing sons. Nothing. It may be of interest to reflect that two of Violet's close friends, who provided much needed moral support and active assistance, were none other than Rudyard and Carrie Kipling, who would go through the same horrific experience when their only son, John, disappeared during the Battle of Loos in 1915. The Kiplings' nightmare is the subject of a recent movie, "Jack."

Violet wrote all the families of the men who died with George, and whose bodies were identified, with as much information as she could find out about the action. All were deeply, deeply grateful. This was rather more than the bare War Office telegram that most families received.

Bostridge's book is a good one. It is a useful addition to any library on the Great War and can complement the more traditional accounts of military and naval activity and those detailing diplomatic and strategic aspects. War is a human endeavour. Bostridge addresses that dimension very well.

Gerard DeGroot has written a gem of a book, Back in Blighty: The British at Home in World War I, that explores domestic matters over the whole war in a thematic fashion in contrast to Bostridge's more episodic and chronological exploration of 1914. In my view, he has provided a hugely helpful corrective to received perceptions of the Great War. Contrary to many, DeGroot avers that the effects of the war on British society were limited. Most of the so-called epochal changes were well underway prior to the war. Certainly, some of these trends were accelerated. Others, like Irish Home Rule, disastrously impeded at great cost. Little, however, was as transforming as widely believed.

That the world was not the same in 1918 as it was in 1914 is a simple truism that perhaps conceals more than it reveals. To be sure Germany was defeated, to be sure the empires of Russia and Austria-Hungary disappeared, to be sure the Ottoman Empire expired with consequences we feel to this day. And, the trends underway as the Victorian era ended and the Edwardian passed, presaged the British Empire's decline and eclipse. DeGroot argues that these outcomes were likely without the Great War hurrying things along.

While DeGroot acknowledges the changes experienced by British society during 
the war years, he notes that these trends were already under way in July 1914 and did not arise unbidden from the fiery furnace of war. He underlines the continuities of the society that went to war in 1914 and the one that emerged victorious in 1918. For a Canadian, or Australian or New Zealander for that matter, the raising of the issue of continuity and deprecation of the "nation building" element associated with the war is certainly not in accord with current national mythology.

This is significant in that underlines the importance of the economic, cultural and political circumstances and trends in a given country. The longue durée as described in another context entirely by Fernand Braudel in his life's work, The Mediterranean, is of more moment than events and personalities. This is, it need hardly be said, the mirror opposite view of the "great man" approach, and perhaps the dominant view of history, particularly among lay audiences. DeGroot reduces in importance the dramatic event and the leading figures in a nation's destiny. In other words, how important is Vimy to Canada as a step to true nationhood? How important is Gallipoli to the ANZAC nations? Current national leaders in Canada and Australia pay effusive homage to the centrality of these battles to national identity and growth. DeGroot suggests another look might be warranted. His perspective provides an interesting contrast to the work of MacMillan and Clark discussed above.

DeGroot's book is organised into three sections, beginning with the approach to war, and its conduct. The second is on the mobilisation of British society to wage war on a scale scarcely conceived before its outbreak. The last covers the results of the war for British society.

In his introduction, DeGroot observes that history is fluid, constantly having to be reinterpreted in light of the preoccupations and perspectives of each succeeding generation. The Great War certainly reflects this truism. A powerful example is DeGroot's discussion of the relations between officers and men, and how Ludendorff's apocryphal remark that the British Army was composed of lions led by donkeys was more accurately turned on its head. That army reflected the society from which it sprang, as all armies must, and the relations between leaders and led was analogous to that in Britain between working class men and their managers. Indeed, the rigidities of the British class system were perpetuated in the trenches, and accepted by both officers and men as the natural way of the world. Alone of the armies that fought the war from the beginning, the British was the only one not to suffer a large scale mutiny, due, at least in part, to the effectiveness of the relationship between leaders and led. (Helped, it must be said, by regular pay, decent food, reasonable amenities, good medical care, docility, fair treatment and good humour.) DeGroot notes that the more literary interpretation of the war, which started to make its mark some ten years after the war's conclusion, was the work of a very small minority of writers, wracked by middle class guilt and anger. By definition this was no more a majority perspective than similar congeries of intellectuals writing today represent the views of "hard working families," as we are occasionally reminded in today's public sphere. Nonetheless, the grip of these writings on public imagination is seemingly intractable.

DeGroot's discussion centres on evidence from the time, not evidence or 
perspectives provided decades later, or coloured by the knowledge of the even greater tragedy of the Second World War. With respect to Great Britain, the chief lessons of the conflict are seemingly associated with the folly of embarking on such endeavours so poorly prepared. The conduct of the war, notwithstanding the undeniable courage of the frontline troops, was frequently inept and at disproportionate cost to the result. British generals, military staffs, industrial preparation and performance, were weighed in the balance and found wanting. That this was so is not surprising, given the national world view, and the level of preparations approved by the politicians, all shaped by the conviction the Royal Navy could shield the country from large-scale involvement in a continental land war. Britain alone of the great powers entered the war with a small volunteer, professional army. The focus of that army in preceding decades had been colonial conflict and policing actions of various scales, mostly small. That future war involving the major powers would be an entirely different affair had been well foreshadowed by the American Civil War, the Franco-Prussian War, and the RussoJapanese War. The blunders and incompetence demonstrated by the British Army during the Boer War should have provided lessons for a future. They were not well absorbed. All in all, the pieces were in place for a poor performance and that is what was delivered. Yet British society absorbed the blows, soldiered on, as it were, and seemingly emerged the stronger. In fact, the Empire was teetering in 1918, with the coup de grace coming with the conclusion of the second great conflagration of the twentieth century. Why? Financial strength had been bled away in meeting the huge costs of the Great War. Kipling's Recessional got it right, two decades prior to 1914.

The last volume I will examine in this survey is Gwynne Dyer's Canada in the Great Power Game 1914-2014. Anyone familiar with Dyer well knows his forthright, trenchant views on many topics, current and past, and so it is no surprise that this book is a polemic. It is a useful one and well worth pondering.

Dyer's basic premise is that Canada lives in a "fireproof house" and has no real reason to embark on military adventures beyond our shores. He tempers this perspective by acknowledging the international and domestic political pressures that the country's leaders had to accommodate and which gravely reduced the real scope for decision. But, as an assertion, it seems reasonable to observe that the Kaiser's Germany could not meaningfully harm Canada in any direct sense. Our participation, therefore, was entirely a question of imperial connection to the United Kingdom and our volunteers fought for that connection. What I think Dyer underplays is the lack of coercion with the act of volunteering and going overseas to fight a "foreign" war. English Canada was very British a century ago. Notwithstanding the emigration of large numbers of east Europeans in the closing decades of the nineteenth century and early twentieth century, the country's institutions and elites were unambiguously British in sentiment and outlook. Indeed, a very large proportion of Canada's volunteer soldiers were recent immigrants from Britain. They were going home to fight for England, not hoary old descendants of United Empire Loyalists or ex-fur trappers uncomprehendingly taking up someone else's quarrel.

Of course, the key fact in Canada's history is that of French Canada, which 
bought none of the arguments for supporting the Empire, let alone signing up to fight a foreign war in that Empire's interest. Indeed, even enthusiasm for enlisting to support "Mother France," presumably of greater resonance, was simply absent. Hence the conscription crisis of 1917-18. This perspective endured through the Second World War (hence the renewed crises over conscription in 1942 and 1944), and remains solidly in place to this day. French Canada is significantly less committed to Canada's international adventures than the rest of the country, grudgingly accepts the American alliance as inevitable given geography, and is less likely to buy into external military obligations of any kind. French Canada epitomises Dyer's argument for the country as a whole.

Dyer's book is divided into chapters covering the key issues that pertain to his theme, with each featuring an "excursion" into some pertinent wider question that has a bearing on the chapter to come. He commences his narrative with a discussion of Canada's participation in the Boer War, which opened the new century. The "excursion" that follows describes the alliance system that grew out of the 1890's into the opposing blocs that fought the Great War. Canada had no role whatsoever in this diplomatic gavotte, yet was bound up in its implications whether it wished to be or not. This is not new ground, of course, but it sets the stage for Dyer's argument that Canada has been repeatedly caught up in rivalries in which we have, at best, an indirect interest, or more accurately, sentiment. Of course, this insight was quite apparent to significant minorities at the time, hence some of Canada's greatest national controversies. For our topic, Dyer is very good in his discussion on the conscription crisis of 1917, and how this exposed the papered over cracks in national unity. Those cracks, it must be acknowledged, remain in place to this day.

Dyer provides some interesting reflections in his "excursion" into the question whether it really mattered who won the Great War. In other words, was the struggle for freedom and democracy merely post-bellum justification for the unjustifiable costs of the conflict just ended? It is a good question, and one generally answered with an affirmation that Wilhelmine Germany represented a grave threat to the world order that needed to be defeated notwithstanding the costs involved. Dyer demurs. It is his contention that any "victory" won by Germany would have been so narrow as to involve a much less dire outcome than that of Versailles, which he contends made the far more appalling Second World War inevitable. It is a worthy question to investigate, albeit utterly speculative, like any counter-factual history.

Dyer's book extends well beyond the period of the Great War, unlike the other volumes in this review. His conclusion that Canadian participation in the First World War was a particularly tragic example of our engagement in conflicts to the present day of little relevance to our real interests will be challenged by many. Taking a good, critical look at where we have been is always appropriate.

Those who have had the patience to explore this rather lengthy examination of eight recent volumes on the Great War can legitimately ask, where has this led us? To conclude that the subject has a vast historiography is to state the very obvious. What more can be said about such well ploughed fields? The answer, as any historian can aver, is that each generation must examine history through its own prism and interpret past 
events accordingly. There is no "final" answer. And, particularly true for the more recent past, there is always new material coming to light that can have a material effect on interpretation.

As the centenary of the Great War passes - and we have already been through the centenary of the opening months in 1914 and early 1915 - there will be ample opportunity to reflect on the events leading to the conflict, its conduct, its effect on the societies of the combatants, and its results. The Great War, in my view, was the single most significant event affecting world history from the ending of the Napoleonic and French Revolutionary Wars in 1815 to our present time. The war was a dramatic watershed separating the time preceding its outbreak, and the modern era. The world prior to 1914 is shadowy and increasingly remote, populated by people somewhat recognisable, but largely alien. The world after 1918 is our world, with geopolitics familiar and understandable, populated with people who are seemingly much nearer to ourselves, and riven by rivalries and resentments born out of that conflict. These issues are, in many cases, anything but fully resolved, and it is likely they won't be for a good while yet. It is entirely appropriate that we examine the outbreak of the Great War and its opening stages as the books reviewed have done. In four more years it will be equally appropriate to examine what will undoubtedly be written regarding the war's conclusion and result. If the books to come match those that have been included in this survey, as well as others I have reluctantly put to one side in the interests of space and mercy to the reader, we are in for a stimulating examination of the birth of the modern world. I am looking forward to it. I hope you are.

Ian Yeates,

Regina, Saskatchewan 
